\title{
DETERMINANTS OF OPPORTUNITY ENTREPRENEURSHIP: A COMPARISON BETWEEN MALES AND FEMALES IN MEXICO
}

\author{
Dra. María Eugenia Elizundia \\ Universidad Anáhuac, Facultad de Economía y Negocios, México \\ e-mail:meelizun@anahuac.mx
}

\begin{abstract}
The majority of research on opportunity entrepreneurship, defined as startups attempts based on perceived business opportunities, has been conducted in either high- or low-income countries. However, the characteristics of these types of entrepreneurship in middle-income countries are very scarce, especially in Latin America.

The purpose of this paper was to analyze and compare the factors that influence opportunity entrepreneurship using the data obtained from the Global Entrepreneurship Monitor (GEM) (Adult Population Survey [APS], 2015), comparing the results between males and females in Mexico.

The empirical research employs a logistic regression model. The main findings highlight that perceived capabilities, work status, income level, and age exert a positive influence on opportunity entrepreneurship, while the factors of fear of failure or education present exerting no influence on this type of venture. Also, the results show that there are no differences between males and females. The research contributes to an increasing literature of this phenomenon in one of the most important countries in this region.
\end{abstract}

Key words: Entrepreneurship, Gender, Latin America; GEM, Mexico.

\begin{abstract}
RESUMEN
La mayor parte de la investigación respecto al emprendimiento de oportunidades, definido como los intentos de startups basados en oportunidades de negocios percibidas, ha sido realizado en países de alto o bajo nivel de ingresos, siendo muy escasos los estudios en países de ingreso medio como muchos de los que componen Latinoamérica. El propósito de este artículo es analizar y comparar los factores que influyen sobre el emprendimiento oportunidades usando datos del Global Entrepreneurship Monitor (GEM) (Adult Population Survey [APS], 2015), comparando los resultados en basea género (hombres y mujeres) en México. Los resultados principales resaltan el rol de las capacidades percibidas, estatus de trabajo, nivel de ingreso, y edad como factores facilitadores de ese tipo de emprendimiento, mientras que otros factores como miedo al fracaso o educación no muestran relaciones significativas. Los resultados tampoco muestran diferencias sustantivas entre hombres y mujeres. De esta manera el artículo contribuye a esta literatura con evidencia empírica en un país de ingreso medio de relevancia en el mundo.
\end{abstract}

Palabras Clave: Entrepreneurship, Gender, Latin America; GEM, Mexico. 


\section{INTRODUCTION}

Entrepreneurship has been widely studied from a variety of fields. It is also recognized as one of the most important engines of economic growth (Van Stel, Carree, \& Thurik, 2005).

Recently, a different variation of entrepreneurship has emerged that attempts to identify individuals seeking entrepreneurship by means of opportunity motivation in contrast with entrepreneurs motivated solely by necessity (those pushed into it by situations of unemployment or dissatisfaction with their previous jobs).

These "opportunity entrepreneurs" have entered their new businesses more prepared and with better background. These latter factors lead to a longer survival rate, higher growth, and usually have more positive effects on the economy in terms of employment and innovation (Hechavarria \& Reynolds, 2009).

Multiple studies have explored the characteristics of necessity and opportunity entrepreneurship in both high- and low-income countries (Sahasranamam \& Sud, 2016; Bergmann \& Sternberg, 2007; Block \& Wagner, 2010. However, the characteristics of these types of entrepreneurship, especially in Latin American countries, have been very scarce in the literature. Thus we find the importance of this line of research, because it is not only important to find who wants to be an entrepreneur but also to find individuals who intertwine entrepreneurship with business opportunities in middle- income countries (Shane S., 2000).

The purpose of this study was to increase knowledge on this type of entrepreneurship by comparing masculine- and feminine-gender characteristics in Mexico, one of the most important countries in this region, utilizing Global Entrepreneurship Monitor (GEM) Adult Population Survey (APS) data for 2015.

This paper is structured in three sections as follows: first, the theoretical framework and a review of literature on this topic; next, we explain the methodology used and the most relevant results, and finally we present important conclusions and future research lines.

\section{REVIEW OF THE LITERATURE ON ENTREPRENEURSHIP BY OPPORTUNITY}

Identifying, selecting, and pursuing the right opportunities are nearly the most important skills of a successful entrepreneur (González-Álvarez \& Solís-Rodríguez, 2011). These skills include knowledge acquisition, competitive scanning, proactive searching, innovative behavior, and collective action (Puhakka, 2006). To be an entrepreneur is to act on the possibility that one has identified an opportunity worth pursuing (McMullen \& Shepherd, 2006).

Opportunities are sometimes recognized by individuals who are not actively searching for them but who have developed the ability to recognize them when they appear (Baron \& Henry). It is this combination of intelligence and creativity that leads entrepreneurs to evaluate multiple ideas and to determine which are most feasible depending on the resources available (Keh, Foo, \& Lim, 2002).

Men and women have different abilities to recognize opportunities (Arenius \& Clercq, 2005). Both have been exposed to different social processes during their lives that give them different types of experience (education, work. and network contacts) (DeTienne \& Chandler, 2007; Gonzalez-Alvarez \& Solis-Rodriguez, 2011). ((Poschke, 
2013) found that female entrepreneurs in developed countries were more likely to be opportunity entrepreneurs (Sahasranamam \& Sud, 2016). Also, (Langowitz \& Minniti, 2007) found evidence that the ability to recognize opportunities and to start a new venture is stronger in men, while (Tang, Kacmar, \& Busenitz, 2012) and (Block \& Wagner (2007) found that there are no differences between opportunity entrepreneurship for male and female entrepreneurs.

\subsection{Perceived Capabilities}

This is defined as the belief that an individual possesses the skills, knowledge, and experience necessary to start their business (Kelley, Singer, \& Harrington, 2015). The capabilities required to become an entrepreneur have changed over time. At present, the capabilities needed for the 21st century include analytical problem solving, innovation and creativity, self-direction and initiative, flexibility and adaptability, critical thinking, communication, and collaboration (Boyles, 2012; Levy \& Murnane, 2007; K. Wagner \& Ziltener, 2008).

Many authors believe that men and women think the same way when they value their perceived capabilities (Birley, 1989; Hamilton, 2003). Others show that women have less confidence in themselves compared to men (Minniti, 2010; Wilson, Kickul, \& Marlino, 2007).

Given that the benefit to countries' economies from individuals able to recognize that they have the necessary skills to perceive opportunities and make them real, it is thus considered an important factor to analyze our first hypothesis:

\section{Hypothesis 1: Perceived capabilities increase the probability of becoming an entrepreneur by opportunity}

\subsection{Fear of Failure}

Fear of failure is considered one of the main problems that affect future entrepreneurs. This fear affects both men and women because sometimes they are able to identify opportunities and think that they have the skills and abilities to start a business but they may not come to pursue them because of this fear (Kelley, Singer \& Harrington, 2015). Some studies demonstrate that opportunity entrepreneurs are willing to accept more risks when compared to necessity entrepreneurs (J. Block, Sandner, \& Spiegel, 2015). Additionally, several studies show that women are much more risk-adverse in terms of exhibiting this negative connotation in their entrepreneurial effort (Carter, Shaw, Lam, \& Wilson, 2007; Diaz Casero, Hernandez, \& Barata, 2007; Minniti, 2010). Although this factor hinders any type of entrepreneurship, it is lower in opportunity entrepreneurs (Wagner, 2005).

Therefore, we propose our next hypothesis:

\section{Hypothesis 2: A lower fear of failure increases the probability of becoming an entrepreneur by opportunity}

\subsection{Education Level}

Research highlights that higher education is more directly correlated with opportunity entrepreneurship because it improves the entrepreneur's perception and capabilities (Autio \& Acs, 2010). With formal education, individuals are better equipped to recognize opportunities in the environment. In addition, higher and formal education allows individuals to acquire abilities and increase their skills to exploit these (Shane, 2000). Thus, our proposal is that individuals who remain within 
the educational system for a longer time are more likely to become opportunity entrepreneurs (Baptista, Karaöz, \& Mendonça, 2014). Hence, our third hypothesis:

Hypothesis 3: The educational level exerts a positive effect on the probability of becoming an entrepreneur by opportunity

\subsection{Social networks}

This factor is defined as the percentage of the population that personally knows an entrepreneur (Kelley et al., 2015. Social networks and contacts with other new and established entrepreneurs comprise an important factor in the decision of becoming an entrepreneur and increase the probability of the latter for success. Several studies reveal the positive impact of knowing entrepreneurs, who take on inspirational roles because they provide motivation, confidence toward their new venture, and provide aspiring entrepreneurs with information for discovering new opportunities (Arenius \& Minniti, 2005; J. H. Block \& Wagner, 2010; Herrera Echeverri, 2009) It was discovered that opportunity entrepreneurs are more likely to have a role model in the family compared to necessity entrepreneurs, while on the other hand, (MoralesGualdrón \& Roig, 2005) found an equally significant positive influence of "knowing an entrepreneur" on opportunity and necessity entrepreneurship.

(Díaz García, 2010; Minniti, 2010;Gatewood et. al., 2009) reported that female entrepreneurial networks are similar to those of males, but tend to be smaller and less diverse, seeking mainly support from their family and from other women.

Therefore, the following hypothesis is proposed:

Hypothesis 4: To know other entrepreneurs personally has a positive effect on the probability of becoming an entrepreneur by opportunity

\subsection{Occupation}

Unemployed persons are more likely to start businesses because they have less to lose (Shane, 2008), but prior employment is expected to impact entrepreneurial preference because entrepreneurs with working experience tend to improve their abilities and business skills, which lowers their likelihood of failure in their venture (Georgellis, Sessions, \& Tsitsianis, 2007). These individuals are more likely to recognize opportunities, are expected to behave differently, and raise more capital, which helps them become more successful than those who do so out of necessity (Sahasranamam \& Sud, 2016; (Hessels, Van Gelderen, \& Thurik, 2008). Therefore, our next hypothesis proposes the following:

Hypothesis 5: Prior working experience has a positive effect on the probability of becoming an entrepreneur by opportunity

\subsection{Income}

Access to business startups may not be available to everyone due to resource constraints (Kim, Aldrich, \& Keister, 2006). If an entrepreneur does not have minimal financial support, it is more probable for him (her) to become an entrepreneur by necessity.

Any venture needs capital to survive. Therefore, having financial sources or personal financial assets will aid in the survival of the business during the difficult initial phase and, as the opportunity develops and financial requirements are added, it will also help to have working capital that supports the new venture (Wright, Lockett, 
Clarysse, \& Binks, 2006); (Arenius \& Clercq, 2005).

Therefore, our hypothesis is as follows:

Hypothesis 6: Income has a positive effect on the probability of becoming an entrepreneur by opportunity

\subsection{Age}

There are contrasting trends of how age influences entrepreneurial disposition. On the one hand, expertise, professional experience, self-confidence, and usually the available capital increase with age, which will increment entrepreneurial alertness to opportunities. On the other hand, as individuals age, the level of family responsibilities increases and the time for engaging in a working life decreases, which weighs against becoming an entrepreneur (Levesque \& Minniti, 2006). Overall, most empirical studies (Sahasranamam \& Sud, 2016); Bergmann \& Sternberg, 2007; Wagner, 2005) confirm a reversed U-shaped relationship between age and entrepreneurial proclivity and also note that opportunity entrepreneurs tend to be older than necessity entrepreneurs.

Therefore, the last hypothesis is presented herein:

\section{Hypothesis 7: Age has a positive effect on the probability of becoming an entrepreneur by opportunity}

\section{METHODOLOGY}

As mentioned previously, this research analyzes the relationship among factors of female entrepreneurship in Mexico. To identify individual-level antecedents of opportunity and necessity entrepreneurship, we employ data from Mexico from the GEM Adult Population Survey (APS) for 2015. This survey captures current Total Entrepreneurial Activity (TEA) in over 100 countries. TEA is defined as the "percentage of the adult population (18-64 years of age) that is either actively involved in starting a new venture or that is the owner/manager of a business that is less than 42 months old" (Kelley, 2015). In addition to TEA, GEM also captures the rate of opportunity and necessity entrepreneurship by gender.

The GEM project was launched in 1999 by two of the most renowned institutions in the area of business and entrepreneurship: Babson College (USA) and the London Business School (UK), seeking to form a homogeneous database among countries. It has been 18 years since this initiative was first inaugurated, beginning with 10 countries. To date, more than 100 economies worldwide have participated in the project (Kelley, et al. 2015).

\subsection{Dependent Variable}

TEAOPP defines entrepreneurs as individuals who started a business who claim have been driven by opportunity, dividing it by gender. Therefore, two binary dependent variables are used in this article: TEAOPPmale and TEAOPPfem. The operationalization of the study variables is presented here.

\begin{tabular}{|l|l|l|}
\hline TEAOPPPmale & Involved in TEA, opportunity, male & $\begin{array}{l}\text { Percentage of men involved in TEA } \\
\text { claiming to be driven by opportunity }\end{array}$ \\
\hline TEOPPPfemale & Involved in TEA, opportunity, female & $\begin{array}{l}\text { Percentage of women involved in TEA } \\
\text { claiming to be driven by opportunity }\end{array}$ \\
\hline
\end{tabular}




\subsection{Independent Variables}

As previously mentioned in this research, it is considered that opportunity entrepreneurship is conditioned by the perception of skills, fear of failure, knowing another entrepreneur, educational level, work status, income level, and age. Of all these factors, the APS (2015) database for Mexico contains binary information, which is also explained here. Variable definition is presented here and can be obtained in GEM and Elizunda (2014).

\begin{tabular}{|c|c|c|}
\hline Suskily & Perceived capabilities & $\begin{array}{l}\text { Individual believes to have the required skills and knowledge to } \\
\text { start a business (Yes }=1, \mathrm{No}=0 \text { ) }\end{array}$ \\
\hline Frfailop & Fear of failure rate & $\begin{array}{l}\text { The individual believes that fear of failure would prevent them } \\
\text { from setting up a business (Yes }=1, \mathrm{No}=0 \text { ) }\end{array}$ \\
\hline Gemeduc & $\begin{array}{l}\text { Respondents were asked their level of } \\
\text { education }\end{array}$ & $\begin{array}{l}\text { Binary variable classified in secondary or less }=0 \text { and post- } \\
\text { secondary }=1\end{array}$ \\
\hline Knowent & Know Startup Entrepreneur Rate & $\begin{array}{l}\text { Individuals who personally know someone who started a business } \\
\text { in the past } 2 \text { years (Yes }=1, \mathrm{No}=0 \text { ) }\end{array}$ \\
\hline Gemwork & $\begin{array}{l}\text { Respondents were asked their work } \\
\text { status }\end{array}$ & Binary variable classified in Not work $=0$ and Work FT; PT $=1$ \\
\hline Gemhhinc & $\begin{array}{l}\text { Respondents were asked their income } \\
\text { level }\end{array}$ & $\begin{array}{l}\text { Binary variable classified as Lower } 33 \%=0 \text { and Middle } 33 \% \text { or } \\
\text { higher }=1\end{array}$ \\
\hline Age & Respondents were asked their age & Individuals' ages \\
\hline Age 2 & & $\begin{array}{l}\text { Age (squared) in order to identify nonlinear relationships between } \\
\text { age and opportunity for start-up activity }\end{array}$ \\
\hline
\end{tabular}

For the statistical analysis, using as basis the methodology employed by (Noguera, Alvarez, Ribeiro, \& Urbano, 2013), Chi-square correlations were used in order to verify whether there was a significant relationship between the dependent variables and the proposed factors, and finally, a Binary logistic regression model was utilized for both groups. The information was analyzed using the SPSS ver. 22.0 statistical software package. Table 2 summarizes the most important characteristics of the research.

\section{RESULTS AND DISCUSSION}

Table 1 presents the mean, Standard Deviation (SD), and correlation matrix for the study variables. In the same manner, Table 2 depicts the results of the logistic regression for the proposed factors. The results indicate that both models are significant. Also, the Nagelkerke score is $>0.10$ and the percentage of correct answers is $>79.8 \%$ for men and $83.8 \%$ for women. 


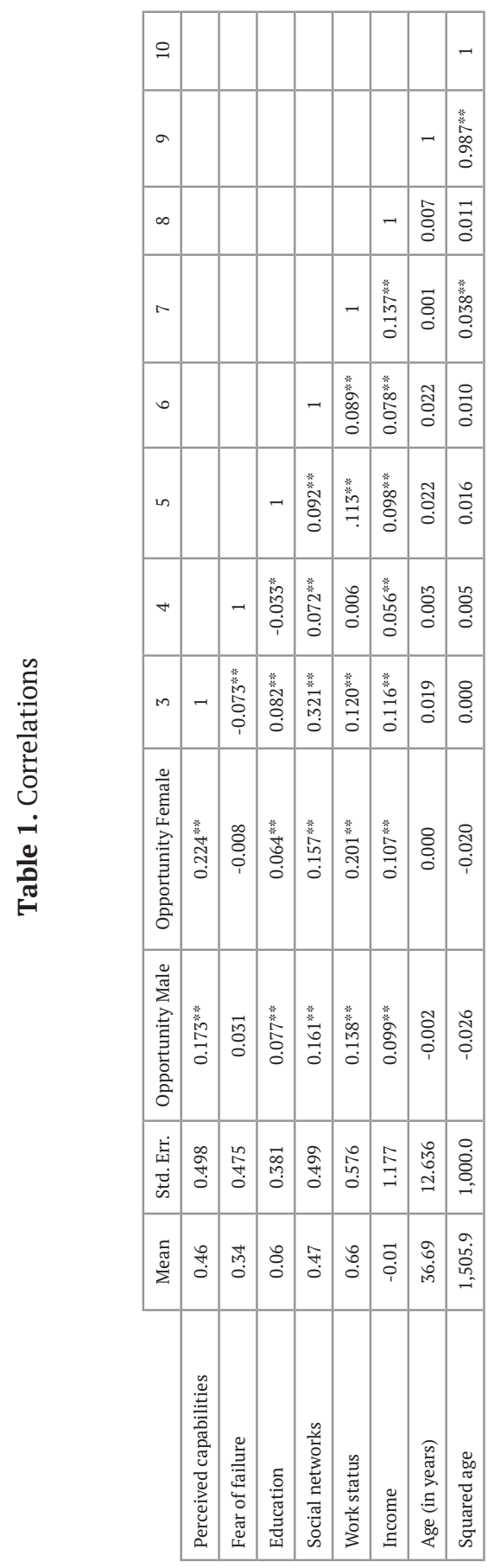


Table 2. Logit regression. Male Mexico

\begin{tabular}{lcccc}
\hline & B & Std. Err. & Sig. & $\operatorname{Exp}(\mathrm{B})$ \\
\hline Perceived capabilities & 0.652 & 0.136 & 0 & 1.919 \\
Fear of failure & 0.215 & 0.131 & 0.102 & 1.24 \\
Know entrepreneurs & 0.511 & 0.134 & 0 & 1.667 \\
Education & 0.224 & 0.152 & 0.141 & 1.251 \\
Income & 0.124 & 0.057 & 0.03 & 1.132 \\
Work status & 1.027 & 0.275 & 0 & 2.792 \\
Age & 0.161 & 0.04 & 0 & 1.174 \\
Squared age & -0.002 & 0.001 & 0 & 0.998 \\
Constant & -5.93 & 0.719 & 0 & 0.003 \\
\hline No. Obs & & 1,784 & & \\
Nagelkerke & 0.127 & & \\
Log pseudolikelihood & & $1,647.365$ & & \\
Percentage correctly & & 79.8 & & \\
predicted & & & \\
\hline
\end{tabular}

Table 3. Logit Regression Female Mexico

\begin{tabular}{lcccc}
\hline & B & Std. Err. & Sig & Ex (b) \\
\hline Perceived capabilities & 1.035 & 0.149 & 0 & 2.815 \\
Fear of failure & -0.063 & 0.144 & 0.66 & 0.939 \\
Know entrepreneurs & 0.479 & 0.143 & 0.001 & 1.615 \\
Education & 0.109 & 0.194 & 0.573 & 1.115 \\
Income & 0.124 & 0.063 & 0.051 & 1.132 \\
Work status & 1.175 & 0.171 & 0 & 3.238 \\
Age & 0.136 & 0.042 & 0.001 & 1.145 \\
Squared age & -0.002 & 0.001 & 0.001 & 0.998 \\
Constant & -5.686 & 0.758 & 0 & 0.003 \\
\hline No. Obs & 1,848 & & & \\
Nagelkerke & 0.186 & & & \\
Log pseudolike-lihood & $1,422.696$ & & & \\
Percentage correctly & 83.8 & & & \\
predicted & & & & \\
\hline
\end{tabular}

On analyzing Hypotheses 1,3,5,6, and 7, which propose that perceived capabilities, knowing someone who started a business in the past 2 years, income level, work status, and age exert an influence on becoming an entrepreneur by opportunity is accepted in both groups.

As we can observe in Table 2, the variable of Perceived capabilities has a positive and significant influence on opportunity entrepreneurship, and this impact is higher in the female group. Specifically, the Odds Ratios (OR) show that the perception of 
entrepreneurial skills increases the probability of being an entrepreneur by 2.81 times for women, compared to by 1.91 times for men. These results are in line with (Brush \& Cooper, 2012; Rosa \& Dawson, 2006), and with (Fairlie \& Robb, 2009), where the authors analyze the influence of perceived capabilities by gender in the entrepreneurship phenomenon.

In the case of knowing other entrepreneurs, there is also a significant impact, the latter nearly the same in both groups. These results are consistent with (Sorenson, Folker, \& Brigham, 2008) and ((Gatewood et al., 2009) although, as (Greve \& Salaff, 2003) note, these networks in females are basically friends and family and the results are in line with the existent literature, where it is shown that social networks provide motivation and confidence for the males and females who exhibit this type of entrepreneurship (Arenius \& Minniti, 2005).

In the case of income level, a positive effect is also revealed in likelihood of opportunity entrepreneurship, which is the same in both groups according to (Cassar, 2006); (Arenius \& Clercq, 2005), who reported that entrepreneurs with higher current income have higher levels of opportunity discovery and that starting with own resources increases business survival (Åstebro \& Bernhardt, 2003) .

Analyzing the variable of work status again demonstrates having a positive and significant impact on both groups, this higher in the female group according to the results of (Giacomin, Guyot, Janssen, \& Lohest) 2007), who reported that prior professional experience exerts a positive impact on opportunity entrepreneurship. The OR shows that income level increases the probability of becoming an entrepreneur by opportunity by 3.23 times for women, compared with 2.79 times for men.

In the case of age, in Table 2, age also reveals a positive and significant influence on becoming an entrepreneur by opportunity in both groups according to (Bergmann \& Sternberg, 2007). Although there are no major differences between both groups, this is the only factor where this is somewhat higher in the male group: its OR shows that work status increases the probability by 1.17 times for men compared with 1.14 times for women. The coefficients of age demonstrate a quadratic relationship with opportunity entrepreneurship, revealing that this probability increases with age until reaching a point where it starts decreasing (Levesque \& Minniti, 2006).

On analyzing Hypotheses 2 and 4, which propose that fear of failure and education exert an influence on individuals to become entrepreneurs by opportunity, we find that these hypotheses are rejected in both groups. These two variables present no significant influence on the probability of becoming an entrepreneur by opportunity in either group. These results do not correspond with those in the existing literature, which argue that less fear of failure encourages opportunity entrepreneurship (Carter et al., 2007; Diaz Casero et al., 2007; Minniti, 2010) and that individuals identify greater opportunities with higher levels of education (Baptista et al., 2014; (Ucbasaran, Westhead, \& Wright, 2008).

It is noteworthy that in the case of analyzing entrepreneurship by opportunity, both masculine- and feminine-gender factors are the same, suggesting that in Mexico, when an individual, independent of their gender, encounters an entrepreneurial opportunity, they act nearly in the same manner, and that both they will attempt to pursue the venture, independently of their fear of failure or educational level. 


\section{CONCLUSIONS}

The main purpose of this paper was to contribute to the existing literature on entrepreneurship by exploring the influence of GEM factors on entrepreneurship by opportunity activity within the Mexican context.

One of the principal findings is that, when analyzing the proposed factors that influence the opportunity entrepreneur, these factors are the same in both males and females. These findings are in line with (Ashe, et. al., 2011), in which the authors show that gender does not influence this type of entrepreneurship.

Also, in disagreement with the existing literature, fear of failure and education present exerting no influence in opportunity entrepreneurs, suggesting that in Mexico when an individual finds an opportunity, he (she) will attempt to pursue independently of these factors.

The results of the factors of perceived capabilities are in line with several studies demonstrating that if males and females believe that they possess the required skills and knowledge to start a business opportunity, entrepreneurship is encouraged (Bhagavatula, Elfring, Van Tilburg, \& Van De Bunt, 2010), and that if they know other entrepreneurs, these connections will help them identify greater opportunities (Sahasranamam \& Sud, 2016), that if they have working experience, this factor will improve recognition of other businesses opportunities (Hessels, Van Gelderen, \& Thurik, 2008), and that if opportunity entrepreneurs tend to be older (Block \& Sandner, 2009; Wagner, 2005), this entrepreneurship type will be exerted, which is the type of entrepreneurial venture type most needed in Latin-American countries.

We think that our study makes important contributions to increasing wisdom in this kind of venture and that it contributes to research on this phenomenon in underdeveloped countries. As a future research line, we propose comparing these results with those of other Latin-American countries.

\section{REFERENCES}

Arenius, P., \& Clercq, D. D. (2005). A network-based approach on opportunity recognition. Small business economics, 24(3), 249-265.

Arenius, P., \& Minniti, M. (2005). Perceptual Variables and Nascent Entrepreneurship. Small Business Economics, 24(3), 233. doi:10.1007/s11187-005-1984-x

Ashe, F., Treanor, L., de los Dolores González, M., \& Husted, B. W. (2011). Gender, human capital, and opportunity identification in Mexico. International Journal of Gender and Entrepreneurship, 3(3), 236-253.

Åstebro, T., \& Bernhardt, I. (2003). Start-up financing, owner characteristics, and survival. Journal of Economics and Business, 55(4), 303-319.

Autio, E., \& Acs, Z. (2010). Intellectual property protection and the formation of entrepreneurial growth aspirations. Strategic Entrepreneurship Journal, 4(3), 234251. 
Baptista, R., Karaöz, M., \& Mendonça, J. (2014). The impact of human capital on the early success of necessity versus opportunity-based entrepreneurs. Small Business Economics, 42(4), 831-847.

Baron, R., \& Henry, R. (2006). The role of expert performance in entrepreneurship: how entrepreneurs acquire the capacity to excel.

Bergmann, H., \& Sternberg, R. (2007). The changing face of entrepreneurship in Germany. Small Business Economics, 28(2), 205-221.

Bhagavatula, S., Elfring, T., Van Tilburg, A., \& Van De Bunt, G. G. (2010). How social and human capital influence opportunity recognition and resource mobilization in India's handloom industry. Journal of Business Venturing, 25(3), 245-260.

Birley, S. (1989). Female Entrepreneurs: are the really any Different? Journal of Small Business Management, 27(1), 32-37.

Block, J., Sandner, P., \& Spiegel, F. (2015). How do risk attitudes differ within the group of entrepreneurs? The role of motivation and procedural utility. Journal of Small Business Management, 53(1), 183-206.

Block, J. H., \& Wagner, M. (2010). Necessity and opportunity entrepreneurs in Germany: Characteristics and earnings differentials.

Boyles, T. (2012). 21st century knowledge, skills, and abilities and entrepreneurial competencies: a model for undergraduate entrepreneurship education. Journal of Entrepreneurship Education, 15, 41.

Brush, C. G., \& Cooper, S. Y. (2012). Female entrepreneurship and economic development: An international perspective. Entrepreneurship \& Regional Development, 24(1), 1-6. doi:10.1080/08985626.2012.637340

Carter, S., Shaw, E., Lam, W., \& Wilson, f. (2007). Gender, Entrepreneurship, and Bank Lending: The Criteria and Processes Used by Bank Loan Officers in Assessing Applications. Entrepreneurship Theory and Practice.

Cassar, G. (2006). Entrepreneur opportunity costs and intended venture growth. Journal of Business Venturing, 21(5), 610-632.

DeTienne, D. R., \& Chandler, G. N. (2007). The Role of Gender in Opportunity Identification. Entrepreneurship: Theory \& Practice, 31(3), 365.

Diaz Casero, J. C., Hernandez, R., \& Barata, M. (2007). Estudiantes universitarios y creación de empresas. Un análisis comparativo entre España y Portugal. Conocimiento, innovación y emprendedores : camino al futuro.

Díaz García, C. y. J. M. J. (2010). Recursos y resultados de las pequeñas empresas: nuevas perspectivas del efecto del género. Cuadernos de Economía y Dirección de Empresa, 42, 151-176. 
Elizunda, M. (2014). Female Entrepreneurship a comparison between Mexico, Brasil and Chile. Estudios de Administración, 21 (2), 1-31.

Fairlie, R. W., \& Robb, A. M. (2009). Gender differences in business performance: evidence from the Characteristics of Business Owners survey. Small Business Economics, 33(4), 375. doi:10.1007/s11187-009-9207-5

Gatewood, E., Brush, C., Carter, N., Greene, P., \& Hart, M. (2009). Diana: a symbol of women entrepreneurs' hunt for knowledge, money, and the rewards of entrepreneurship. Small Business Economics, 32(2), 129-144. doi:10.1007/s11187008-9152-8

Georgellis, Y., Sessions, J., \& Tsitsianis, N. (2007). Pecuniary and non-pecuniary aspects of self-employment survival. The Quarterly Review of Economics and Finance, 47(1), 94-112.

Giacomin, O., Guyot, J.-L., Janssen, F., \& Lohest, O. (2007). Novice creators: personal identity and push pull dynamics.

Gonzalez-Alvarez, N., \& Solis-Rodriguez, V. (2011). Discovery of entrepreneurial opportunities: a gender perspective. Industrial Management \& Data Systems, 111(5), 755-775.

Greve, A., \& Salaff, J.W.(2003). Social networks and entrepreneurship. Entrepreneurship theory and practice, 28(1), 1-22.

Hamilton, L. (2003). Competitive advantages and the smes: the role of distinctive competences as determinants of success, are there differences across gender, sector, and size? (Dissertation/Thesis), Universitat Autònoma de Barcelona.

Hechavarria, D., \& Reynolds, P. (2009). Cultural norms \& business start-ups: the impact of national values on opportunity and necessity entrepreneurs. International Entrepreneurship \& Management Journal, 5(4), 417.

Herrera Echeverri, H. (2009). Research into social and entrepreneurship networks: A literature review and future agenda. Innovar, 19(33), 19-33.

Hessels, J., Van Gelderen, M., \& Thurik, R. (2008). Entrepreneurial aspirations, motivations, and their drivers. Small Business Economics, 31(3), 323-339.

Keh, H. T., Foo, M. D., \& Lim, B. C. (2002). Opportunity evaluation under risky conditions: The cognitive processes of entrepreneurs. Entrepreneurship theory and practice, $27(2), 125-148$.

Kelley, D., Singer, S., \& Harrington, M. (2015). Global Entrepreneurship Monitor.

Kim, P. H., Aldrich, H. E., \& Keister, L. A. (2006). Access (Not) Denied: The Impact of Financial, Human, and Cultural Capital on Entrepreneurial Entry in the United States, 5 . 
Langowitz, N., \& Minniti, M. (2007). The entrepreneurial propensity of women. Entrepreneurship theory and practice, 31(3), 341-364.

Levesque, M., \& Minniti, M. (2006). The effect of aging on entrepreneurial behavior. Journal of Business Venturing, 21(2), 177.

Levy, F., \& Murnane, R. (2007). How computerized work and globalization shape human skill demands. Learning in the global era: International perspectives on globalization and education, 158-174.

McMullen, J. S., \& Shepherd, D. A. (2006). Entrepreneurial action and the role of uncertainty in the theory of the entrepreneur. Academy of Management review, 31(1), 132-152.

Minniti, M. (2010). Female Entrepreneurship and Economic Activity. European Journal of Development Research, 22(3), 294-312. doi:10.1057/ejdr.2010.18

Morales-Gualdrón, S. T., \& Roig, S. (2005). The new venture decision: An analysis based on the GEM project database. The International Entrepreneurship and Management Journal, 1(4), 479-499.

Noguera, M., Alvarez, C., Ribeiro, D., \& Urbano, D. (2013). Sociocultural Factors and Female Entrepreneurship in the Innovative Service Sector in Catalonia: A Qualitative Analysis. In J. J. M. Ferreira, M. Raposo, R. Rutten, \& A. Varga (Eds.), Cooperation, Clusters, and Knowledge Transfer (pp. 141-162): Springer Berlin Heidelberg.

Poschke, M. (2013). Who becomes an entrepreneur? Labor market prospects and occupational choice. Journal of Economic Dynamics and Control, 37(3), 693-710.

Puhakka, V. (2006). Effects of social capital on the opportunity recognition process. Journal of Enterprising Culture, 14(02), 105-124.

Rosa, P., \& Dawson, A. (2006). Gender and the commercialization of university science: academic founders of spinout companies. Entrepreneurship and Regional Development, 18(4), 341-366.

Sahasranamam, S., \& Sud, M. (2016). Opportunity and necessity entrepreneurship:A comparative study of India and China. Academy of Entrepreneurship Journal, 22(1), 21-40.

Shane S., V., S. (2000). The Promise of Entrepreneurship as a Field of Research. In (Vol. 25, pp. 217-226): The Academy of Management Review.

Shane, S. A. (2008). The illusions of entrepreneurship: The costly myths that entrepreneurs, investors, and policy makers live by: Yale University Press.

Sorenson, R. L., Folker, C. A., \& Brigham, K. H. (2008). The collaborative network orientation: Achieving business success through collaborative relationships. Entrepreneurship Theory and Practice, 32(4), 615-634. 
Tang, J., Kacmar, K. M. M., \& Busenitz, L. (2012). Entrepreneurial alertness in the pursuit of new opportunities. Journal of Business Venturing, 27(1), 77-94.

Ucbasaran, D., Westhead, P., \& Wright, M. (2008). Opportunity identification and pursuit: Does an entrepreneur's human capital matter? Small Business Economics, 30(2), 153-173.

Van Stel, A., Carree, M., \& Thurik, R. (2005). The Effect of Entrepreneurial Activity on National Economic Growth. Small Business Economics, 24(3), 311.

Wagner, J. (2005). Nascent necessity and opportunity entrepreneurs in Germany evidence from the regional entrepreneurship monitor (REM). Labor and Demography, 506004.

Wagner, K., \& Ziltener, A. (2008). The nascent entrepreneur at the crossroads: entrepreneurial motives as determinants for different types of entrepreneurs. Discussion Papers on Entrepreneurship and Innovation, Swiss Institute for Entrepreneurship.

Wilson, F., Kickul, J., \& Marlino, D. (2007). Gender, Entrepreneurial Self-Efficacy, and Entrepreneurial Career Intentions: Implications for Entrepreneurship Education. Entrepreneurship Theory and Practice, 31(3), 387-406. doi:10.1111/j.15406520.2007.00179.x

Wright, M., Lockett, A., Clarysse, B., \& Binks, M. (2006). University spin-out companies and venture capital. Research policy, 35(4), 481-501. 